\title{
KEJADIAN INFEKSI MENULAR SEKSUAL BERDASARKAN KARAKTERISTIK SOSIAL DEMOGRAFI DI PUSKESMAS II DENPASAR UTARA TAHUN 2014-2016
}

\author{
Kadek Yulita Lestari Dewi*, Desak Nyoman Widyanthini, I Ketut Tangking Widarsa \\ Program Studi Kesehatan Masyarakat Fakultas Kedokteran Universitas Udayana \\ *Email: yulitalestari37@yahoo.com
}

\begin{abstract}
ABSTRAK
Infeksi Menular Seksual (IMS) adalah infeksi yang penularannya terutama melalui hubungan seksual. Di Indonesia, jumlah kasus IMS pada tahun 2014 terjadi sebanyak 5608 kasus. Dinas Kesehatan Provinsi Bali mencatat jumlah pasien IMS yang ditemukan pada tahun 2013 sebanyak 9.202 orang. Jumlah ini meningkat sebanyak 62,17\% pada tahun 2014 dan mengalami penurunan sebanyak 61,82\% pada tahun 2015. Data yang diperoleh dari Dinas Kesehatan Kota Denpasar menunjukkan bahwa dari keseluruhan kasus di Kota Denpasar pada tahun 2016, kasus IMS tertinggi berada di wilayah Puskesmas II Denpasar Utara yaitu sebanyak 36,94 \%. Tujuan penelitian ini adalah untuk mengetahui kejadian IMS berdasarkan karakteristik sosial demografi meliputi jenis penyakit, umur, jenis kelamin, pendidikan terakhir, status perkawinan, pekerjaan, kelompok risiko, pemakaian kondom dan jumlah pasangan seksual pada bagian IMS di Puskesmas II Denpasar Utara tahun 20142016. Penelitian ini merupakan penelitian deskriptif dengan desain penelitian cross sectional retrospektif. Populasi dan sampel pada penelitian ini adalah seluruh pasien yang berkunjung ke Klinik IMS Puskesmas II Denpasar Utara periode tahun 2014-2016 yang diperoleh secara total sampling. Data sekunder yang diperoleh selanjutnya diolah secara statistik dengan menggunakan stata. Hasil penelitian menunjukkan bahwa kejadian IMS lebih tinggi pada kelompok umur 41-50 sebanyak 25\%, subjek laki-laki sebanyak 26,4\%, tidak pernah sekolah sebanyak $12,5 \%$, subjek dengan status kawin sebanyak $37,6 \%$, pekerjaan berisiko sebanyak $25,5 \%$, kelompok WPS sebanyak 60\%, subjek yang kadang-kadang memakai kondom sebanyak 18,2\% dan jumlah pasangan seksual $>1$ sebanyak 39,4\%. Kesimpulan dari penelitian ini adalah kejadian IMS di Puskesmas II Denpasar Utara tahun 2014-2016 yaitu 7,4\%-13\%. Kejadian IMS lebih tinggi pada kelompok umur 41-50 dengan pekerjaan berisiko, kelompok WPS dan jumlah pasangan seksual $>1$. Tiga jenis IMS yang paling sering terjadi di Puskesmas II Denpasar Utara dalam 3 tahun terakhir yaitu Urethritis Non-GO disusul Servisitis dan Kandidiasis. Diharapkan sasaran dalam pelaksanaan program IMS tidak hanya bagi penderita namun juga bagi pasangannya dan tidak hanya menyasar kelompok risiko seperti WPS namun juga pelanggan PS.
\end{abstract}

Kata Kunci: Kejadian, IMS, karakteristik, cross sectional retrospektif

\begin{abstract}
Sexually transmitted infections (STIs) are transmitted infections mainly through sexual contact. In Indonesia, the number of STI cases in 2014 reached 5608 cases. The Bali Provincial Health Service recorded 9,202 STI patients found in 2013. This number increased by $62.17 \%$ in 2014 and decreased by $61.82 \%$ in 2015 . Data obtained from the Denpasar City Health Office showed that of all cases in Denpasar City in 2016, the highest STI cases were in the Puskesmas area II North Denpasar as much as $36.94 \%$. The purpose of this study was to determine the incidence of STIs based on socio-demographic characteristics including the type of disease, age, sex, recent education, marital status, occupation, risk group, condom use and number of sexual partners in the STI section at Puskesmas II Denpasar Utara in 2014-2016. This research is a descriptive study with a retrospective cross sectional research design. The population and sample in this study were all patients who visited the IMS Clinic II North Denpasar Health Center for the period 2014-2016 obtained in total sampling. The secondary data obtained are then processed statistically using stata. The results showed that the incidence of STIs was higher in the 41-50 age group by $25 \%$, male subjects by $26.4 \%$, never attending school by $12.5 \%$, subjects with marital status by $37.6 \%$, occupations at risk as much as $25.5 \%$, FSW group as much as $60 \%$, subjects who sometimes used condoms as much as $18.2 \%$ and the number of sexual partners $>1$ were $39.4 \%$. The conclusion of this study is the incidence of
\end{abstract}


STIs in Puskesmas II Denpasar Utara in 2014-2016, namely 7.4\% -13\%. The incidence of STIs was higher in the 4150 age group with risk jobs, FSW groups and number of sexual partners $>1$. Three types of STIs that most often occur in Puskesmas II Denpasar Utara in the last 3 years, namely Non-GO Urethritis followed by Cervicitis and Candidiasis. It is expected that the target in the implementation of the IMS program is not only for sufferers but also for their partners and not only targeting risk groups such as WPS but also PS customers.

Keywords: Occurrence, STI, characteristic, retrospective cross sectional

\section{PENDAHULUAN}

Infeksi Menular Seksual (IMS) adalah infeksi yang penularannya terutama melalui hubungan seksual (Djuanda, 2007). Menurut WHO (2016) lebih dari 1 juta IMS diperoleh setiap hari. Secara epidemiologi penyakit ini tersebar di seluruh dunia, angka kejadian paling tinggi tercatat di Asia Selatan dan Asia Tenggara, diikuti Afrika bagian Sahara, Amerika Latin dan Karibia (WHO, 2016). Dalam beberapa tahun terakhir ini terlihat adanya kecenderungan peningkatan prevalensi penyakit IMS di berbagai negara termasuk Indonesia (Kusnan, 2013).

Di Indonesia, jumlah kasus IMS pada tahun 2014 terjadi sebanyak 5608 kasus. Survey Demografi dan Kesehatan Indonesia (SDKI) tahun 2012 menunjukkan bahwa sekitar 12\% wanita usia 15-49 tahun yang pernah melakukan hubungan seksual secara aktif dilaporkan mengalami IMS dan atau gejalanya. Dinas Kesehatan Provinsi Bali mencatat jumlah pasien IMS yang ditemukan pada tahun 2013 sebanyak 9.202 orang. Jumlah ini meningkat sebanyak $62,17 \%$ pada tahun 2014 dan mengalami penurunan sebanyak $61,82 \%$ pada tahun 2015. Berdasarkan laporan Tahunan Pencegahan, Penanggulangan, Penyakit dan Penyehatan Lingkungan (P2PL) kota Denpasar pada tahun 2013 tercatat jumlah pasien yang berkunjung ke layanan IMS sebanyak 6.349 orang. Tahun 2014 jumlahnya menurun sebanyak $47,46 \%$, tahun
2015 mengalami peningkatan sebanyak 6\%, dan pada tahun 2016 jumlahnya menurun sebanyak $4,47 \%$.

Data yang diperoleh dari Dinas Kesehatan Kota Denpasar menunjukkan bahwa dari keseluruhan kasus di Kota Denpasar pada tahun 2016, kasus IMS tertinggi berada di wilayah Puskesmas II Denpasar Utara yaitu sebanyak 36,94\%. Berdasarkan catatan SIHA IMS Puskesmas II Denpasar Utara, periode tahun 2016 jumlah pasien baru yang berkunjung ke layanan IMS sebanyak 1233 orang, dengan jumlah pasien IMS yang ditemukan sebanyak 85 orang dan jumlah kasus IMS sebanyak 98 kasus.

Beberapa faktor yang mungkin berkontribusi terhadap kejadian IMS adalah faktor sosio demografi dan perilaku. Variabel-variabel tersebut diantaranya adalah umur, jenis kelamin, pendidikan terakhir, status perkawinan, pekerjaan, kelompok risiko, pemakaian kondom dan jumlah pasangan seksual.

Menurut Kusnan (2013) bahwa faktor umur sangat erat hubungannya dengan penyakit IMS. Menurut Nova (2014), di Kota Bengkulu didapatkan hasil dari 10 orang $(19,6 \%)$ responden yang berpendidikan tinggi, sebanyak 2 orang responden (3,9\%) terdiagnosis positif IMS dan klien yang berpendidikan dasar terdapat 41 orang $(80,4 \%)$ semua terdiagnosis positif IMS. 
Menurut Dyna (2014) penderita IMS lebih banyak terdapat pada perempuan.

Hasil penelitian Muda (2014) menunjukkan bahwa ada hubungan signifikan antara status perkawinan $(\mathrm{p}=0,001)$, dan tindakan pemakaian kondom $(\mathrm{p}=0,009)$ dengan kejadian IMS, dengan nilai $\alpha(0,05)$. Menurut hasil penelitian Satriani (2015) menyatakan bahwa ada hubungan pekerjaan dengan kejadian IMS pada wanita pasangan usia subur dimana wanita usia subur dengan pekerjaan yang berisiko memiliki peluang terkena IMS 12,06 kali dibandingkan wanita dengan pekerjaan yang tidak berisiko.

Menurut Pertiwi (2015) kelompok yang mempunyai risiko tinggi untuk terpapar IMS salah satunya adalah Wanita Pekerja Seksual (WPS) (80\%). Penggunaan kondom yang tidak konsistensi merupakan faktor risiko untuk terjadinya infeksi menular seksual sebesar 1,8 kali lebih (Arifin, 2012). Semakin banyak jumlah pasangan seksual maka semakin besar kemungkinan salah satu diantaranya menularkan IMS. Menurut Astutik (2011) jumlah pasangan seksual yang banyak merupakan faktor risiko terjadinya IMS.

Tingginya angka kunjungan dan kasus yang ditemukan di Puskesmas II Denpasar Utara tidak terlepas dari keberadaan klinik IMS dan kesadaran masyarakat untuk memeriksakan diri ke layanan kesehatan ketika mengalami keluhan IMS. Dengan memahami gambaran infeksi menular seksual yang terjadi pada masyarakat dan distribusi populasi berisiko tinggi terhadap infeksi ini akan sangat membantu dalam upaya pencegahan penularan IMS dan pengobatan dini terhadap pengidapnya. Oleh karena itu, penulis melakukan penelitian mengenai kejadian Infeksi Menular Seksual (IMS) berdasarkan karakteristik sosial demografi di Puskesmas II Denpasar Utara tahun 20142016.

\section{METODE}

Penelitian ini merupakan penelitian deskriptif dengan pendekatan cross sectional retrospektif. Penelitian dilakukan di Puskesmas II Denpasar Utara pada Bulan Maret sampai Mei 2017. Sampel dari penelitian ini adalah seluruh pasien yang berkunjung di klinik IMS Puskesmas II Denpasar Utara pada Bulan Januari 2014 sampai Desember 2016 yang berjumlah 3036 orang dan memenuhi kriteria inklusi yaitu memiliki data yang lengkap pada SIHA IMS Puskesmas II Denpasar Utara.

Teknik pengambilan sampel yang digunakan adalah total sampling. Data penelitian dikumpulkan dari data sekunder pada catatan medis pasien di SIHA IMS Puskesmas II Denpasar Utara periode tahun 2014-2016. Data selanjutnya dicatat dalam form data sekunder. Data yang terkumpul dianalisis menggunakan analisis univariate.

HASIL

Kejadian IMS di Puskesmas II Denpasar Utara Tahun 2014-2016 


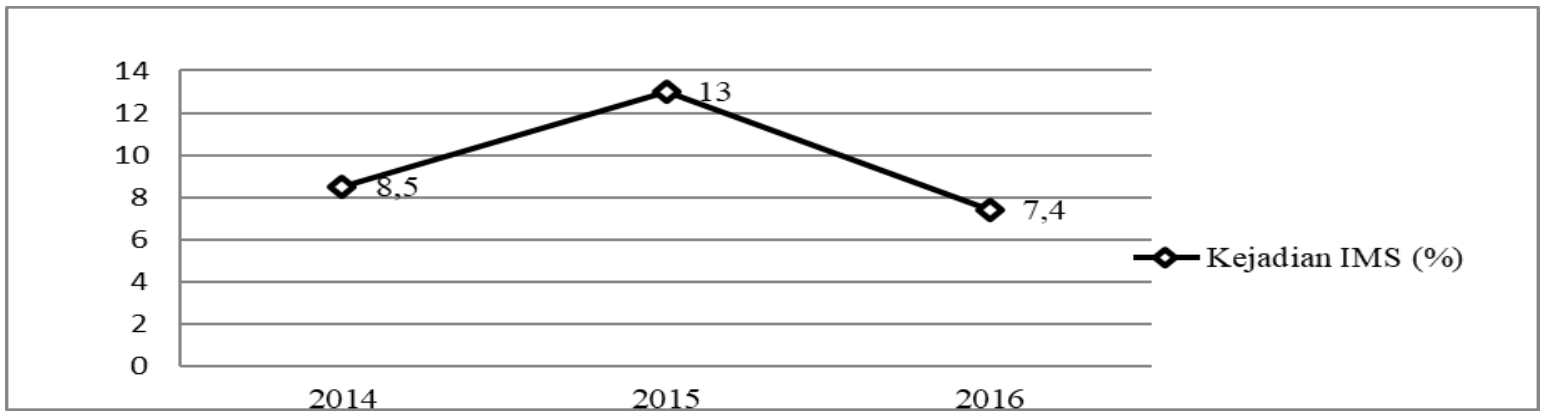

Gambar 1 Diagram Garis Kejadian IMS di Puskesmas II Denpasar Utara Tahun 2014-2016

Dari Gambar 1 prevalensi kejadian kemudian meningkat pada tahun 2015 IMS dari tahun 2014 sampai 2016 sebesar 13\%. Dan menurun pada tahun 2016 menunjukkan angka yang berfluktuatif. menjadi 7,4\%.

Tahun 2014 kejadian IMS sebesar 8,5\%.

Kejadian IMS Berdasarkan Jenis Infeksi di Puskesmas II Denpasar Utara Tahun 2014-2016

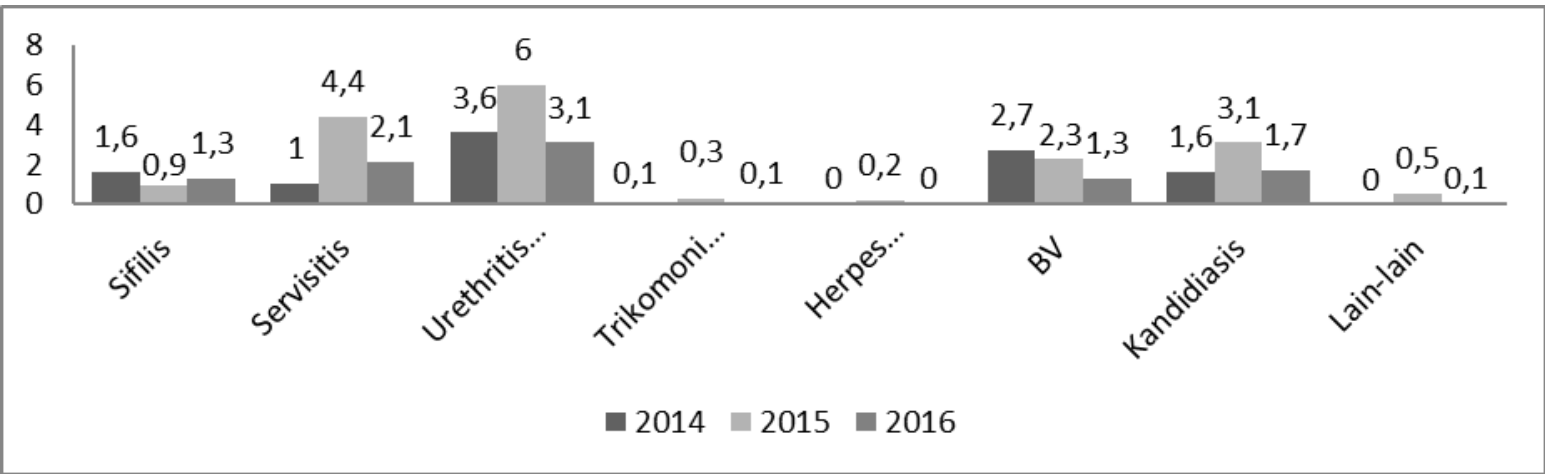

Gambar 2 Diagram Batang Kejadian IMS Berdasarkan Jenis Infeksi di Puskesmas II Denpasar Utara Tahun 2014-2016

Berdasarkan Gambar 2, tiga jenis Infeksi Menular Seksual (IMS) yang sering terjadi pada tahun 2014 yaitu Urethritis Non-GO (3,6\%), BV (2,7\%), Sifilis dan Kandidiasis (1,6\%). Pada tahun 2015 jenis IMS yang sering terjadi yaitu Urethritis NonGO (6\%), Servisitis $(4,4 \%)$ dan Kandidiasis $(3,1 \%)$. Pada tahun 2016 tiga jenis IMS yang sering terjadi yaitu Urethritis Non-GO Tabel 1 Kejadian IMS Berdasarkan Karakteristik Responden di Puskesmas II Denpasar Utara Tahun 2014-2016

\begin{tabular}{cccc}
\hline Karakteristik & $\begin{array}{c}\text { Jumlah } \\
\text { Pengunjung }\end{array}$ & Frekuensi & $\begin{array}{c}\text { Kejadian } \\
\text { IMS (\%) }\end{array}$ \\
\hline
\end{tabular}

\section{Umur (tahun)}


Arc. Com. Health Desember 2018

ISSN: 2527-3620

$31-40$

855

99

11,6

41-50

232

58

25,0

$>50$

66

8

12,1

Jenis Kelamin

Laki-laki

26,4

Perempuan

2449

141

5,8

\section{Pendidikan terakhir}

Tidak pernah sekolah $\quad 56$

12,5

$\mathrm{SD} /$ sederajat

545

$\mathrm{SMP} /$ sederajat

813

7

11,2

SMA/sederajat

1422

7,0

Akademi/perguruan tinggi

200

10,4

11,5

Status Perkawinan

Kawin

460

173

37,6

Tidak kawin

2535

109

4,3

Cerai hidup

35

12

34,3

Cerai mati

6

2

33,3

Pekerjaan

Tidak bekerja

Pekerjaan berisiko

Pekerjaan tidak berisiko

2717

250

9,2

\section{Kelompok Risiko}

Wanita Pekerja Seks

20

12

60,0

Pelanggan PS

83

38

45,8

Waria

74

30

40,5

Pasangan risti

456

159

34,9

LSL

86

22

25,6

Lain-lain

2317

35

1,5

\section{Pemakaian Kondom}

Tidak pernah

2345

182

7,8

Kadang-kadang

589

107

18,2

Selalu

102

7

6,9

Jumlah pasangan seksual

$\leq 1$ orang

2856

225

7,9

$>1$ orang

180

71

39,4 
Berdasarkan tabel 1 kejadian IMS lebih tinggi ditemukan pada kelompok umur 41-50 tahun (25\%), laki-laki $(26,4 \%)$, status kawin $(37,6 \%)$, pekerjaan berisiko $(25,5 \%)$, kelompok WPS (60\%), kadangkadang memakai kondom (18,2\%) dan jumlah pasangan seksual $>1 \quad(39,4 \%)$. Sebaliknya tidak tampak ada perbedaan kejadian yang signifikan pada tingkat pendidikan.

\section{DISKUSI}

Kejadian IMS di Puskesmas II Denpasar Utara pada tahun 2014 sebesar 8,5\% meningkat pada tahun 2015 sebesar 13\% dan menurun pada tahun 2016 sebesar 7,3\%. Hal ini disebabkan karena SIHA IMS di Puskesmas II Denpasar Utara dimulai pada tahun 2014 sehingga pelaksanaannya masih belum maksimal. SIHA mulai aktif dilaksanakan pada tahun 2015 sehingga lebih banyak kasus IMS yang ditemukan. Kejadian IMS menurun pada tahun 2016 karena berdasarkan program IMS di Puskesmas II Denpasar Utara, dengan pengobatan dan pembagian kondom yang rutin diberikan pada penderita maka kasus yang ditemukan juga menurun.

Kejadian IMS berdasarkan jenis penyakit yang terjadi pada tahun 2014 diurutkan dalam 3 terbanyak yaitu Urethritis Non-GO (3,6\%), BV (2,7\%), Sifilis dan Kandidiasis (1,6\%). Pada tahun 2015 yaitu Urethritis Non-GO (6\%), Servisitis $(4,4 \%)$ dan Kandidiasis (3,1\%). Pada tahun 2016 yaitu Urethritis Non-GO (3,1\%), Servisitis (2,1\%) dan Kandidiasis (1,7\%). Urethritis Non-GO adalah penyakit yang paling sering terjadi dari tahun 2014-2016. Sebagian besar Urethritis disebabkan oleh infeksi akibat paparan seksual yang tidak aman (Bloomberg, 2006). Perempuan dan laki-laki memiliki risiko yang sama tertular penyakit ini, namun kadang-kadang tidak menunjukkan gejala khususnya pada perempuan. Hasil penelitian ini berbeda dengan hasil penelitian Sridana (2012) bahwa IMS yang paling sering terjadi di Puskesmas II Denpasar Selatan periode Januari sampai Juni 2012 adalah Servisitis dengan jumlah 200 kasus (33,3\%) diikuti oleh Gonore sebanyak 14 kasus (2,3\%), serta Sifilis dan Urethritis masing-masing sebanyak 10 kasus (1,7\%).

Dari hasil penelitian berdasarkan umur di Puskesmas II Denpasar Utara tahun 2014 sampai 2016 kejadian IMS lebih tinggi pada kelompok umur 41-50 tahun dengan prevalensi sebesar $25 \%$. Hasil penelitian ini berbeda dengan hasil penelitian CDC pada tahun 2010 yang menyatakan kelompok usia 15-19 tahun merupakan kelompok usia tertinggi pengidap IMS, yang diikuti oleh kelompok usia 20-24 tahun.

Kejadian IMS di Puskesmas II Denpasar Utara berdasarkan jenis kelamin tahun 2014 sampai 2016 lebih tinggi pada laki-laki dengan prevalensi 26,4\%. Hasil penelitian ini tidak sesuai dengan hasil penelitian Sridana (2012) di Puskesmas II Denpasar Selatan bahwa jumlah subjek perempuan jauh lebih banyak daripada subjek laki-laki dengan perbedaan yang sangat jauh yaitu 561 orang subjek perempuan $(93,3 \%)$ dan 40 orang subjek laki-laki (6,7\%).

Dilihat dari jenis kelamin, kejadian IMS pada subjek laki-laki hampir 4 kali lebih banyak dibandingkan perempuan. Berdasarkan data, tidak semua perempuan memiliki risiko atau angka kejadian IMS 
yang rendah. Perempuan yang termasuk dalam kelompok berisiko memiliki prevalensi kejadian yang lebih tinggi dibandingkan laki-laki. Misalnya pada wanita pekerja seks cenderung memiliki angka kejadian yang lebih tinggi diantara kelompok berisiko lain. Demikian pula dengan laki-laki tidak selalu memiliki risiko yang lebih rendah dari perempuan. Pada laki-laki yang termasuk dalam kelompok berisiko seperti waria dan pelanggan PS cenderung memiliki angka kejadian lebih tinggi. Sehingga tidak dapat dikatakan hanya jenis kelamin yang mempengaruhi kejadian IMS namun dipengaruhi oleh perilaku dan faktor risiko yang dihadapi.

Dari hasil penelitian berdasarkan pendidikan terakhir di Puskesmas II Denpasar Utara tahun 2014 sampai 2016 kejadian IMS lebih tinggi pada subjek yang tidak pernah sekolah dengan prevalensi sebesar $12,5 \%$. Hasil penelitian ini sesuai dengan hasil penelitian Nova (2014) yang menyatakan bahwa dari 19,6\% responden yang berpendidikan tinggi, sebanyak 3,9\% terdiagnosis positif IMS dan klien yang berpendidikan dasar terdapat 80,4\% semua terdiagnosis positif IMS. Pendidikan terakhir subjek tidak dapat menentukan tinggi rendahnya risiko kelompok subjek tersebut terhadap kejadian IMS.

Hasil penelitian berdasarkan status perkawinan di Puskesmas II Denpasar Utara tahun 2014 sampai 2016 didapatkan bahwa kejadian IMS lebih tinggi pada subjek yang memiliki status kawin dengan prevalensi sebesar 37,6\% namun tidak jauh berbeda dengan status cerai baik cerai hidup $(34,3 \%)$ maupun cerai mati (33,3\%). Menurut hasil penelitian Muda (2014), bahwa insiden penyakit menular seksual lebih tinggi pada orang yang belum menikah, bercerai atau orang yang terpisah dari keluarganya bila dibandingkan dengan orang yang sudah menikah karena pemenuhan kebutuhan seksualnya terpenuhi. Subjek dengan status cerai cenderung memiliki jumlah pasangan lebih dari satu orang sehingga risiko untuk mengalami IMS menjadi lebih tinggi. Hasil penelitian ini sesuai dengan hasil survei menurut Surveilans Terpadu Biologi dan Perilaku pada Tahun 2011 yang menyatakan bahwa status pernikahan tertinggi pada pria dengan potensial resiko tinggi adalah menikah sebesar $71 \%$. Subjek dengan status menikah juga memungkinkan untuk memiliki lebih dari satu pasangan seksual baik itu dengan alasan kebutuhan biologis atau hiburan sehingga lebih rentan untuk tertular IMS (Ekawati, 2014).

Dari hasil penelitian berdasarkan pekerjaan di Puskesmas II Denpasar Utara tahun 2014 sampai 2016 kejadian IMS lebih tinggi pada kelompok subjek dengan pekerjaan berisiko dengan prevalensi sebesar 25,5\%. Pekerjaan berisiko yang termasuk dalam penelitian ini berdasarkan data SIHA adalah orang yang bekerja di tempat hiburan, sopir, nelayan, anak buah kapal, PSK, buruh kasar dan petugas kesehatan. Hasil penelitian ini sesuai dengan hasil penelitian Satriani (2015) menyatakan ada hubungan pekerjaan dengan kejadian IMS pada wanita pasangan usia subur dimana wanita usia subur dengan pekerjaan yang berisiko memiliki peluang terkena IMS 12,06 kali dibandingkan wanita dengan pekerjaan yang tidak berisiko. Setiap pekerjaan memiliki risiko yang juga dapat 
menentukan pola penyakit yang akan diderita oleh pekerjanya.

Hasil penelitian berdasarkan kelompok risiko di Puskesmas II Denpasar Utara tahun 2014 sampai 2016 kejadian IMS lebih tinggi pada kelompok WPS dengan prevalensi sebesar $60 \%$. Hasil penelitian ini sesuai dengan hasil penelitian Widodo (2009) bahwa penyebab terbesar penyebaran IMS adalah para wanita pekerja seks (WPS). WPS dengan pola kehidupan yang bergantiganti pasangan merupakan salah satu kelompok yang berisiko tinggi terkena penularan IMS. Hasil penelitian ini berbeda dengan hasil penelitian dari KPA (2011) bahwa gay/LSL memiliki faktor risiko yang tinggi dalam penyebaran IMS. Infeksi Menular Seksual merupakan penyakit yang disebabkan oleh infeksi organisme, namun ternyata dalam penyebarannya sangat dipengaruhi oleh pola perilaku dan gaya hidup seseorang.

Berdasarkan pemakaian kondom di Puskesmas II Denpasar Utara tahun 2014 sampai 2016 kejadian IMS lebih tinggi pada subjek yang kadang-kadang memakai kondom dengan prevalensi sebesar 18,2\%. Hasil penelitian ini sesuai dengan hasil penelitian Arifin (2012), bahwa penggunaan kondom yang tidak konsistensi merupakan faktor risiko untuk terjadinya IMS sebesar 1,8 kali lebih tinggi. Hasil penelitian ini juga sesuai dengan teori yang menyatakan bahwa melakukan hubungan seksual yang aman yaitu dengan menggunakan pelindung seperti kondom sangat membantu dalam mengurangi risiko penularan melalui hubungan seksual. Pemakaian kondom pada kelompok risiko merupakan isu penting dalam kebijakan penanggulangan IMS.
Melakukan hubungan seksual yang aman yaitu dengan menggunakan pelindung seperti kondom akan sangat mengurangi risiko penularan melalui hubungan seksual (French, 2015).

Kejadian IMS di Puskesmas II Denpasar Utara berdasarkan jumlah pasangan seksual tahun 2014 sampai 2016 lebih tinggi pada subjek dengan jumlah pasangan seksual $>1$ dengan prevalensi sebesar 39,4\%. Hasil penelitian ini sesuai dengan hasil penelitian Satriani (2015), bahwa wanita usia subur dengan jumlah pasangan seks $>1$ berisiko terkena IMS 14.11 kali dibandingkan WUS dengan pasangan seks $\leq 1$. Salah satu cara pencegahan IMS adalah melakukan hubungan seksual hanya dengan satu orang. Jika seseorang memiliki pasangan seks lebih dari satu maka akan berpotensi untuk tertular IMS. Banyaknya pasangan seksual memberikan banyak peluang risiko pada seks yang tidak aman yang merupakan faktor penting dalam penularan IMS

\section{SIMPULAN}

Kejadian IMS di Puskesmas II Denpasar Utara tahun 2014-2016 secara keseluruhan adalah 7,4\%-13\%, kejadian IMS lebih tinggi pada kelompok umur 41-50 sebanyak $25 \%$, subjek laki-laki $(26,4 \%)$, tidak pernah sekolah $(12,5 \%)$, subjek dengan status kawin $(37,6 \%)$, pekerjaan berisiko $(25,5 \%)$, kelompok WPS (60\%), subjek yang kadang-kadang memakai kondom $(18,2 \%)$ dan jumlah pasangan seksual $>1 \quad(39,4 \%)$. Tiga jenis IMS yang paling sering terjadi di Puskesmas II Denpasar Utara dalam 3 tahun terakhir yaitu Urethritis Non-GO disusul Servisitis dan Kandidiasis. Diharapkan bagi Puskesmas sasaran dalam pelaksanaan 
program IMS tidak hanya bagi penderita namun juga bagi pasangannya dan tidak hanya menyasar kelompok risiko seperti WPS namun juga pelanggan PS.

\section{DAFTAR PUSTAKA}

Arifin, N.F. (2012). Penggunaan Kondom Dan Vaginal Higiene Sebagai Faktor Risiko Kejadian Infeksi Menular Seksual Pada Wanita Pekerja Seks Di Lokasi Batu 24 Kabupaten Bintan. Semarang.

Astutik, Y.D. (2011). Faktor yang Berhubungan Dengan Kejadian Gonore Pada Waria di Surabaya Tahun 2011.

Bloomberg, Michael R. (2006). Urethritis. The

New York City Department of Health and Mental Hygiene.

Djuanda, Adhi. 2007. Ilmu Penyakit Kulit

Dan Kelamin. Jakarta: Balai Penerbit FKUI

Dyna, Sylvana, dkk. (2014). Karakteristik

Penderita Infeksi Menular Seksual Di

Wilayah Kerja Puskesmas Bandar Baru Tahun 2013.

Ekawati, Ni Komang, dkk. (2014). Laporan

Hasil Penelitian Studi Tentang Perilaku

Beresiko Pelaku Pekerja Pariwisata (Sopir Travel dan Pramuwisata) Terhadap HIV/AIDS di Kota Denpasar Provinsi Bali.

French, K. (2015). Kesehatan Seksual. Jakarta: Bumi Medika.

KPA Nasional, (2011). Laporan KPA Nasional Tahun 2010.

Kusnan, Adius. (2013). Analisis Hubungan

Determinan Kejadian Penyakit Infeksi Menular Seksual (IMS) Pada Wanita Penjaja Seksual (WPS).
Muda, Febrianingsih. (2014). Faktor-Faktor Yang Berhubungan Dengan Kejadian Infeksi Menular Seksual Pada Pasien Yang Datang Berobat Di Klinik Infeksi Menular Seksual Puskesmas Limba B Kecamatan Kota Selata Kota Gorontalo.

Nova. (2014). Hubungan Pendidikan Dan Pengetahuan Dengan Kejadian Penyakit Menular Seksual Pada Klien Di Wilayah Kerja Puskesmas Penurunan Kota Bengkulu Tahun 2014.

Pertiwi, Maria Ratna, dkk. (2013). Hubungan Antara Penggunaan Kondom Dengan Kejadian Penyakit Menular Seksual Pada Wanita Pekerja Seksual Di Wilayah Puskesmas Duren Kecamatan Bandungan Kabupaten Semarang.

Satriani, Ade Verientic. (2015). Analisis

Faktor Risiko Infeksi Menular Seksual (IMS) Pada Wanita Usia Subur (WUS) di Layanan IMS Puskesmas 23 Ilir Tahun 2015.

SDKI. (2012). Survei Demografi dan Kesehatan Indonesia. Available: indonesia.unfpa.org/application/assets/ publications/sdki_pria_. (Accessed: 7 Januari 2017).

Sridana, Made Edwin. (2012). Karakteristik Infeksi Menular Seksual (IMS) Pada Puskesmas II Denpasar Selatan Periode Januari-Juni Tahun 2012

WHO. (2016). Sexually Transmitted Infections (STIs). Available: http://www.who.int/mediacentre/factsh eets/fs110/en/ (Accessed: 3 Agustus 2017).

Widodo. Edy. (2009). Praktik Wanita Pekerja Seks (WPS) Dalam Pencegahan Penyakit Infeksi Menular Seksual (IMS) Dan HIV\&AIDS Di Lokalisasi Koplak, 
Arc. Com. Health Desember 2018

ISSN: 2527-3620

Vol. 5 No. $2: 33$ - 42

Kabupaten Grobogan. Jurnal Promosi

Kesehatan Indonesia, 4 (2):120-12 